\title{
IMPLEMENTASI SISTEM PENJAMINAN MUTU INTERNAL (SPMI) DI PROGRAM STUDI PENDIDIKAN SEJARAH FAKULTAS KEGURUAN DAN ILMU PENDIDIKAN UNIVERSITAS MAHASARASWATI DENPASAR
}

\author{
I Made Legawa, Ida Bagus Nyoman Wartha,Ida Bagus Brata \\ Email: legawa.made@unmas.ac.id
}

\begin{abstract}
Abstrak
Sesuai dengan amanat Undang-Undang Sistem Pendidikan Nasional (Undang-Undang Nomor 20 Tahun 2003 Pasal 50) bahwa pengelolaan Pendidikan nasional didasarkan atas kebijakan nasional dan standar nasional untuk menjamin mutu Pendidikan nasional. Kebijakan tersebut dikuatkan lagi dalam pasal 51 ayat (2) menjelaskan bahwa pengelolaan satuan pendidikan tinggi dilaksanakan berdasarkan prinsip otonomi, akuntabilitas, jaminan mutu, dan evaluasi yang transparan. Selanjutnya pada Undang Undang Nomor 12 Tahun 2012 Pasal 52 dinyatakan bahwa penjaminan mutu pendidikan tinggi merupakan kegiatan sistemik untuk meningkatkan mutu pendidikan tinggi secara berencana dan berkelanjutan, serta penjaminan mutu sebagaimana dimaksud dilakukan melalui prinsip penetapan, pelaksanaan, evaluasi, pengendalian, dan peningkatan (PPEPP) standar Pendidikan Tinggi.

Prodi Pendidikan Sejarah FKIP Unmas Denpasar telah medeklarasikan diri melalui visi sebagai prodi yang mampu menghasilkan sarjana pendidikan sejarah yang bermutu berbasis kearifan lokal berwawasan global. Komitmen tersebut dituangkan dalam kebijakan mutu akademik dengan prinsip pengelolaan berbudaya mutu. Konskuensi dari komitmen tersebut, prodi Sejarah membentuk satuan penjaminan mutu internal yang disebut dengan Unit Penjaminan Mutu (UPM). UPM sebagai unit pengendali pelaksanaan Sistem Penjaminan Mutu Internal (SPMI) merencanakan, melaksanakan, dan mengembangkan sistem penjaminan mutu akademik dan nonakademik dengan menyusun naskah berupa Kebijakan SPMI, Manual SPMI, Standar SPMI, dokumen formulir SPMI, dan Standar Oprational Prosedure (SOP).

Kebijakan mutu Prodi Pendidikan Sejarah memuat komitmen mutu mengedepankan pelayanan untuk menghasilkan lulusan yang memuaskan stakeholders. Untuk itu, standar mutu telah dirumuskan sebanyak 36 standar melampui Standar Nasional Pendidikan Tinggi (SNDikti). Silkus pelaksanaan SPMI di Prodi Sejarah disesuaikan dengan prinsip PPEPP. UPM Prodi Pendidikan Sejarah sebagai pengendali SPMI senantiasa melakukan Monev dan Audit secara berencana dan berkelanjutan sebagai upaya perbaikan mutu akademik secara kontinu (continuous quality improvement). Tindakan baik yang dilakukan untuk menjamin prningkatan mutu akademik secara berkelanjutan dengan mengikuti kegitan Universitas Mahasaraswati Denpasar Annual Quality Award (UMDAQA) yang berlangsung setiap tahun.
\end{abstract}

Kata Kunci: SPMI, Kebijakan mutu, Komitmen Mutu, Monev, dan Audit Mutu Akademik. 


\section{Pendahuluan}

Kebijakan Sistem Penjaminan Mutu Internal (SPMI) di Program Studi (Prodi) Pendidikan Sejarah Fakultas Keguruan dan Ilmu Pendidikan (FKIP) Universitas Mahasaraswati (Unmas) Denpasar, sejalan dengan kebijakan Rektor Unmas Denpasar untuk menyelenggarakan Pendidikan tinggi dan mengelola Perguruan tinggi di Unmas Denpasar dengan komitmen mutu. Komitmen mutu tersebut dituangkan dalam kebijakan mutu pendidikan di seluruh unit pengelola termasuk di Prodi Pendidikan Sejarah dengan prinsip pengelolaan berbudaya mutu. Komitmen mutu pengelola prodi Pendidikan Sejarah adalah menyelenggarakan pendidikan dengan mengutamakan kepuasan stakeholder melalui manajemen taat azas, memenuhi aturan sesuai peraturan dan perundang-undangan, dan senantiasa melakukan perbaikan secara berkelanjutan di bidang akademik dan nonakademik.

Komitmen mutu Pendidikan di Prodi Pendidikan Sejarah searah dengan upaya pencapaian visi prodi yaitu menjadikan program studi yang mampu menghasilkan sarjana pendidikan sejarah yang bermutu berbasis kearifan lokal berwawasan global. Untuk mengendalikan ketercapaian visi Prodi, dirumuskan kerangka kerja dan tujuan penyelenggaraan pendidikan sebagai berikut:

1.Meningkatkan kenyamanan proses pembelajaran dengan model pembelajaran inovatif

2.Memenuhi rasio dosen dan mahasiswa untuk pemenuhan aturan perundang-undangan

3.Meningkatkan akurasi proses pembelajaran sesuai dengan standar mutu

4. Mencapai kualitas pembelajaran, menghasilkan lulusan berkarakter dengan berperilaku santun, kreatif, mandiri, berbudaya, berkemampuan kewirausahaan serta berdaya saing global.

5. Mencapai kuantitas dan kualitas penelitian, pengabdian kepada masyarakat di berbagai bidang dan dimanfaatkan untuk kesejahteraan masyarakat.

6.Mencapai pengembangan dan penyebarluasan IPTEKS.

7. Mewujudkan sistem manajemen perguruan tinggi sehat dengan komitmen pelayanan paripurna.

8. Menghasilkan lulusan yang memenuhi standar kompetensi lulusan (SKL) pada level 6 untuk memenuhi kebutuhan stakeholders.

9. Mengembangkan profesionalisme dosen dalam bidang pendidikan dan pembelaran, penelitian ilmiah dan pengabdian kepada msyarakat di berbagai skim 
10. Mewujudkan prodi yang sehat dan penyelenggaraan serta pengelolaan tridarma perguruan tinggi yang memenuhi good governance

11. Meningkatkan kompetensi lulusan dan sumber daya manusia baik dosen maupun tenaga kependidikan dalam bidang publikasi dan penulisan artikel

12. Meningkatkan kualitas bahan pembelajaran untuk menunjang capaian pembelajaran lulusan.

13. Meningkatkan profesionalisme pengelolaan perpustakaan dalam menunjang proses pembelajaran

14. Mengoptimalkan pelayanan dan penggunaan laboratorium sejarah bagi mahasiswa

15. Meningkatkan budaya mutu dalam rangka mengefektifkan evaluasi untuk pengukuran kinerja prodi

16. Meningkatkan kenyamanan dan keamanan di lingkungan kampus

17. Meningkatkan kualitas dan kuantitas kerjasama serta mengefektifkan implementasinya Untuk mengendalikan kinerja prodi dalam mencapai visi, oleh satuan penjaminan mutu internal di prodi dilakukan monev-in dan audit secara priodik dan berkelanjutan baik di bidang akademik maupun di bidang nonakademik. Tujuan monev-in dan audit tersebut, untuk mengetahui apakah telah tercapai standar mutu yang ditetapkan apa belum, sehingga dapat menentukan arah pengendalian standar mutu oleh Kaprodi. Kajian terhadap hasil monevin maupun audit sangat penting untuk menetapkan tindakan pengelola dalam meningkatkan standar mutu di prodi. Pemenuhan dokumen pelaksanaan system penjaminan mutu di Prodi Pendidikan Sejarah telah disiapkan secara maksimal. Dokumen terkait dengan penjaminan mutu akademik disesuaikan dengan regulasi dan Pedoman Sistem Penjaminan Mutu Pendidikan Tinggi yang dikeluarkan oleh Kementerian Riset, Teknologi, dan Pendidikan Tinggi Direktorat Jenderal Pembelajaran dan Kemahasiswaan Direktorat Penjaminan Mutu (2017). Untuk menjamin pelaksanaan SPMI di Prodi Pendidikan Sejarah Unmas Denpasar berjalan terarah, sistematis dan berkelanjutan, unit pelaksana SPMI di prodi telah menyusun program kerja yang didasarkan atas kerangka kerja yang jelas. Diawali dengan mengidentifikasi isu yang ada dan berkembang secara internal dan eksternal prodi, mengidentifikasi kebutuhan dan harapan prodi, melakukan analisis resiko, serta menetapkan sasaran mutu prodi.

\section{Organisasi Sistem Penjaminan Mutu Internal}

120 | Seminar Nasional Sejarah ke 4 Jurusan Pendidikan Sejarah Universitas Negeri Padang 
Undang-Undang No . 20 tahun 2003 tentang sistem Pendidikan Nasional, pasal 51 ayat (2) secara eksplisit menjelaskan bahwa pengelolaan satuan pendidikan tinggi dilaksanakan berdasarkan prinsip otonomi, akuntabilitas, jaminan mutu, dan evaluasi yang transparan (Sekneg RI,2003). Undang Undang Nomor 12 Tahun 2012 Bab III Pasal 52 menyatakan bahwa penjaminan mutu Pendidikan Tinggi merupakan kegiatan sistemik untuk meningkatkan mutu Pendidikan Tinggi secara berencana dan berkelanjutan, serta penjaminan mutu sebagaimana dimaksud dilakukan melalui penetapan, pelaksanaan, evaluasi, pengendalian, dan peningkatan standar Pendidikan Tinggi (KemenSegneg RI,2012:37). Dalam upaya menjamin mutu penyelenggaraan pendidikan tinggi, Universitas Mahasaraswati (Unmas) Denpasar sejak tahun 1999 telah berkomitmen untuk menyelenggarakan Tri Dharma secara seimbang dan bermutu. Sejalan dengan komitmen tersebut, Unmas Denpasar membentuk Badan Penjaminan Mutu (BPM) sesuai Surat Keputusan Rektor Unmas Denpasar No.K.114/C.13.02/Unmas/I/2008. Untuk mengoptimalkan kinerja SPMI di seluruh unit di lingkungan Unmas Denpasar, Satuan Penjamin Mutu Internal di lengkapi dengan membentuk Gugus Penjaminan Mutu (GPM) berada di tingkat fakultas/program pascasarjana dan Unit Penjaminan Mutu (UPM) di Prodi di lingkungan Unmas Denpasar berdasarkan Surat Keputusan Rektor Unmas Denpasar, Nomor: K.554/C.13.02/Unmas/V/2013 tanggal 02 Mei 2013. Sesuai dengan ruang lingkup tugas dan kewenangan BPM Unmas Denpasar sebagai pengendali sistem manajemen mutu, BPM dirubah menjadi Lembaga Penjaminan Mutu Internal (LPMI) dengan Surat Keputusan Rektor Unmas Denpasar, Nomor: K.400/C.06.01/Unmas/IV/2018 tanggal 13 April 2018.

LPMI Unmas Denpasar bertugas dalam merencanakan, memfasilitasi, menyiapkan dokumen Kebijakan SPMI, dokumen Manual SPMI, dokumen Standar mutu, dokumen formulir SPMI, Standar operational procedure (SOP). Secara rinci jabaran tugas pokok LPMI dapat diuraikan sebagai berikut:

a. Merencanakan, melaksanakan, dan mengembangkan sistem penjaminan mutu akademik dan nonakademik, diawali dengan membangun komitmen di tingkat manajemen dari seluruh aras yang dimulai dari tingkat Unmas Denpasar, fakultas sampai pada program studi, sekaligus menyamakan persepsi mengenai pelaksanaan SPMI serta mensosialisasikannya kepada seluruh pemangku kepentingan pencapaian visi Unmas Denpasar untuk menjadi komitmen kerja dengan mengedepankan mutu dalam melaksanakan kegiatan pendidikan di lingkungan Unmas Denpasar.

121 | Seminar Nasional Sejarah ke 4 Jurusan Pendidikan Sejarah Universitas Negeri Padang 
b. Merencanakan, merancang, dan menyusun naskah berupa Kebijakan SPMI meliputi bidang Akademik dan nonakademik, Manual SPMI, Standar SPMI Unmas Denpasar, dokumen formulir SPMI, dan Standar Oprational Prosedure (SOP).

c. Secara berkala dan kemitraan memberikan bantuan teknis dalam membangun dan mengembangkan sistem penjaminan mutu akademik dan nonakademik pada fakultas/program studi untuk mewujudkan pelayanan prima.

d. Melaksanakan monitoring dan audit mutu internal disemua aras Unmas Denpasar mengenai implementasi SPMI untuk mengetaui ketercapaian standar mutu sesuai siklus PPEPP.

Gugus Penjaminan Mutu (GPM) bertugas untuk mengendalikan mutu di tingkat fakultas, dengan tugas menyusun:

1) Rencana kerja dan anggaran tahunan (RKAT) fakultas/pascasarjana (pendampingan)

2) Kebijakan SPMI fakultas

3) Manual SPMI fakultas

4) Standar mutu fakultas

5) Dokumen kegiatan dan formulir SPMI

6) Melakukan monevin dan pelacakan pelaksanaan SPMI di tingkat fakultas, serta mengkaji, dan merumuskan tindak lanjut

7) Memonev pemenuhan dokumen kegiatan akreditasi prodi dan laporan PDDikti di fakultas

8) Mendampingi dekan melakukan analisis SWOT kondisi fakultas berdasarkan ED prodi sebagai bahan merumuskan Evaluasi Diri fakultas

9) Membuat laporan tertulis kinerja dekan meliputi bidang akademik dan nonakademik setiap semester kepada LPMI

Unit Penjaminan Mutu sebagai pengendali mutu di tingkat Prodi bertugas menyusun standar mutu dan sasaran mutu, menginventarisir dokumen mutu, dan menetapan tindakan strategis untuk perbaikan ataupun pencapaian standar mutu, secara rinci dapat dijelaskan sebagai berikut:

a) Rencana kerja dan anggaran tahunan prodi (pendampingan)

b) Kebijakan SPMI prodi 
c) Manual SPMI prodi

d) Standar mutu prodi

e) Dokumen kegiatan dan formulir SPMI prodi

f) Melakukan monevin dan pelacakan pelaksanaan SPMI di tingkat prodi, serta mengkaji, dan merumuskan tindak lanjut

g) Memonev pemenuhan dokumen kegiatan akreditasi prodi dan laporan PDDikti di prodi

h) Mendampingi prodi melakukan analisis SWOT kondisi prodi sebagai bahan merumuskan Evaluasi Diri prodi

i) Membuat laporan tertulis kinerja prodi meliputi bidang akademik dan nonakademik setiap semester kepada LPMI melalui GPM

\section{Tahapan Sasaran Mutu Prodi}

Tindakan strategis dalam pelaksanaan SPMI di Prodi Pendidikan Sejarah adalah menentukan sasaran mutu berbasis prodi, sehingga kebijakan mutu prodi senantiasa menuntut adanya peningkatan sasaran mutu. Kebijakan mutu dan sasaran mutu prodi didokumentasikan dalam Rencana Strategis dan Rencana Oprasional Prodi Pendidikan Sejarahyang selanjutnya secara lebih rinci dan terukur kebijakan mutu dan sarasan mutu dituangkan dalam Rencana Program Kerja/Pengembangan program studi. Sasaran mutu Prodi Pendidikan Sejarah disusun mengacu kepada kerangka kerja kebijakan mutu yang meliputi bidang akademik yakni Tri Dharma PT berupa pelaksanaan pendidikan tinggi, pelaksanaan penelitian ilmiah, dan pelaksanaan pengabdian kepada masyarakat serta nonakademik yang terdiri dari tata kelola (meningkatkan komitmen Kaprodi dalam menjaga mutu), Sumber Daya Manusia, sarana dan prasarana, keuangan, dan kemahasiswaan.

Tahapan-tahapan pencapaian sasaran mutu terukur dari rencana dan pelaksanaan kegiatan dan anggaran tahunan (RKAT). Tahapan pencapaian sasaran mutu secara langsung menginformasikan ketercapaian standar mutu akademik dan nonakademik yang telah ditetapkan di prodi. Untuk selanjutnya, secara bertahap dan berkelanjutan dalam rentang waktu tertentu diukur status pencapaiannya (pemetaan mutu) setiap tahun, dalam hal mana dapat menggambarkan ketercapaian standar mutu dari tingkat prodi, fakultas sampai di tingkat Unmas Denpasar. Demikian secara bertingkat dan priodik sasaran mutu dan standar mutu dievaluasi 
serta ditetapkan dari tingkat prodi, fakultas, dan akhirnya dapat mencerminkan pencapaian sasaran dan standar mutu di tingkat Unmas Denpasar.

Sasaran Mutu Utama Prodi Pendidikan Sejarah Unmas Denpasar meliputi: (1) pertumbuhan mahasiswa minimum 10\%, (2) angka kelulusan dengan tepat waktu minimum 85\%, (3) IPK ratarata setiap semester minimum 3,50, (4) masa tunggu kerja maksimum 6 bulan, (5) rating ketidaksesuaian maksimum 1\%, (6) indeks kepuasan mahasiswa minimum 75\%, (7) peningkatan penelitian masuk ke cluster utama, dan (8) peningkatan pengabdian kepada masyarakat menuju cluster sangat memuaskan.

Sebagai ilustrasi Matrik Sasaran Mutu dapat dijabarkan dalam tabel berikut.

\begin{tabular}{|c|c|c|c|c|c|}
\hline NO & $\begin{array}{l}\text { PRO } \\
\text { SES }\end{array}$ & TAHAPAN & $\begin{array}{c}\text { KERANGKA } \\
\text { KERJA }\end{array}$ & $\begin{array}{l}\text { SASARAN } \\
\text { MUTU }\end{array}$ & $\begin{array}{c}\text { TARGET } \\
\text { CAPAIA } \\
\mathbf{N}\end{array}$ \\
\hline I & \multicolumn{4}{|c|}{ ISU INTERNAL } & \\
\hline 1 & Prodi & \begin{tabular}{|l} 
a. \\
menerimasisw \\
a baru \\
sesuai \\
dengan \\
daya \\
tampung \\
di prodi
\end{tabular} & $\begin{array}{l}\text { Meningkatkan } \\
\text { kenyamanan } \\
\text { proses } \\
\text { perkuliahan }\end{array}$ & 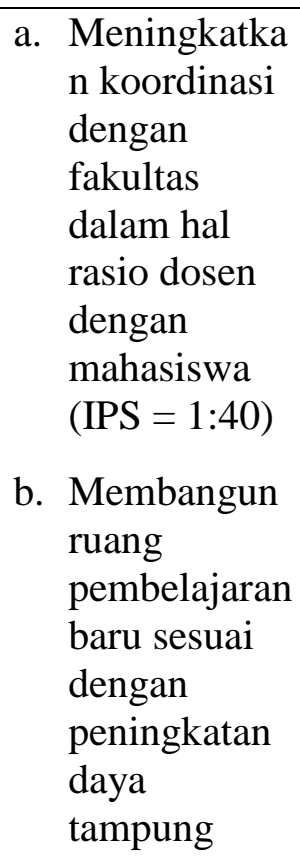 & $70 \%$ \\
\hline & & $\begin{array}{l}\text { b. Melakuk } \\
\text { an } \\
\text { proses } \\
\text { rekrutm } \\
\text { en dosen }\end{array}$ & $\begin{array}{l}\text { Memenuhi rasio } \\
\text { dosen dan } \\
\text { mahasiswa } \\
\text { untuk } \\
\text { pemenuhan } \\
\text { standar dosen }\end{array}$ & $\begin{array}{l}\text { Pemenuhan } \\
\text { persentase } \\
\text { jumlah dosen } \\
\text { tetap } 60 \% \text { dari } \\
\text { jumlah } \\
\text { keseluruhan } \\
\text { dosen di pProdi } \\
\text { Pendidikan } \\
\text { Sejarah }\end{array}$ & $100 \%$ \\
\hline
\end{tabular}

124 | Seminar Nasional Sejarah ke 4 Jurusan Pendidikan Sejarah Universitas Negeri Padang 


\begin{tabular}{|c|c|c|c|c|c|}
\hline 2 & $\begin{array}{l}\text { Seleksi } \\
\text { Mahasis } \\
\text { wa Baru }\end{array}$ & $\begin{array}{l}\text { c.Merancan } \\
\text { g sistem } \\
\text { pendaftara } \\
\text { n secara } \\
\text { online }\end{array}$ & $\begin{array}{l}\text { Mewujudkan } \\
\text { sistem } \\
\text { manajemen } \\
\text { perguruan tinggi } \\
\text { sehat dengan } \\
\text { komitmen } \\
\text { pelayanan } \\
\text { paripurna. }\end{array}$ & $\begin{array}{l}\text { Memperbaiki } \\
\text { sistem } \\
\text { penerimaan } \\
\text { mahasiswa baru } \\
\text { secara online }\end{array}$ & $100 \%$ \\
\hline \multirow[t]{3}{*}{3} & $\begin{array}{l}\text { Proses } \\
\text { Pembelaj } \\
\text { aran }\end{array}$ & $\begin{array}{l}\text { d.Monitorin } \\
\text { g terhadap } \\
\text { kehadiran } \\
\text { dosen serta } \\
\text { memberikan } \\
\text { punishment } \\
\text { terhadap } \\
\text { dosen yang } \\
\text { tidak } \\
\text { disiplin }\end{array}$ & $\begin{array}{l}\text { Meningkatkan } \\
\text { akurasi proses } \\
\text { pembelajaran } \\
\text { sesuai dengan } \\
\text { aturan } \\
\text { perundangan }\end{array}$ & $\begin{array}{l}\text { Menambah } \\
\text { jumlah tatap } \\
\text { muka dosen } \\
\text { untuk memenuhi } \\
16 \text { minggu tatap } \\
\text { muka }\end{array}$ & $100 \%$ \\
\hline & & $\begin{array}{l}\text { e.Sosialisasi } \\
\text { dan } \\
\text { workshop } \\
\text { RPS } \\
\text { terhadap } \\
\text { dosen }\end{array}$ & $\begin{array}{l}\text { Mencapai } \\
\text { kualitas } \\
\text { pembelajaran, } \\
\text { menghasilkan } \\
\text { lulusan } \\
\text { berkarakter } \\
\text { dengan } \\
\text { berperilaku } \\
\text { santun, kreatif, } \\
\text { mandiri, } \\
\text { berbudaya, } \\
\text { berkemampuan } \\
\text { kewirausahaan } \\
\text { serta berdaya } \\
\text { saing global }\end{array}$ & $\begin{array}{l}\text { Mewajibkan } \\
\text { setiap dosen } \\
\text { menyusun RPS } \\
\text { untuk mata } \\
\text { kuliah yang } \\
\text { diampu }\end{array}$ & $100 \%$ \\
\hline & & $\begin{array}{l}\text { f.Monitorin } \\
\text { g dan } \\
\text { mengevalua } \\
\text { si kinerja } \\
\text { dosen } \\
\text { dalam } \\
\text { mengajar }\end{array}$ & $\begin{array}{l}\text { Mengembangka } \\
\mathrm{n} \\
\text { profesionalisme } \\
\text { dosen dalam } \\
\text { bidang } \\
\text { pendidikan dan } \\
\text { pengajaran, } \\
\text { penelitian ilmiah } \\
\text { dan pengabdian } \\
\text { kepada } \\
\text { msyarakat di }\end{array}$ & $\begin{array}{l}\text { Melaksanakan } \\
\text { perkuliahan di } \\
\text { kelas } 1 \text { sks } \\
\text { selama } 50 \text { menit }\end{array}$ & $100 \%$ \\
\hline
\end{tabular}




\begin{tabular}{|c|c|c|c|c|c|}
\hline & & & berbagai skim & & \\
\hline 3 & $\begin{array}{l}\text { Unit } \\
\text { Penjamina } \\
\text { n Mutu } \\
\text { (UPM) }\end{array}$ & $\begin{array}{l}\text { g.Mengefek } \\
\text { tifkan } \\
\text { pelaksanaan } \\
\text { pedoman } \\
\text { kebijakan } \\
\text { mutu serta } \\
\text { mengoptima } \\
\text { lkan } \\
\text { penggunaan } \\
\text { formulir } \\
\text { standar } \\
\text { mutu }\end{array}$ & $\begin{array}{l}\text { Meningkatkan } \\
\text { budaya mutu } \\
\text { dalam rangka } \\
\text { mengefektifkan } \\
\text { evaluasi untuk } \\
\text { pengukuran } \\
\text { kinerja prodi }\end{array}$ & $\begin{array}{l}\text { Meningkatkan } \\
\text { sistem } \\
\text { manajemen } \\
\text { mutu melalui } \\
\text { Unmas } \\
\text { Denpasar } \\
\text { Annual Quality } \\
\text { Award } \\
\text { (UMDAQA) } \\
\text { setiap tahun }\end{array}$ & $100 \%$ \\
\hline II & \multicolumn{4}{|c|}{ ISU EKSTERNAL } & \\
\hline 4 & $\begin{array}{l}\text { Profesio } \\
\text { nal } \\
\text { Dosen } \\
\text { dan } \\
\text { Tenaga } \\
\text { Kependi } \\
\text { dikan }\end{array}$ & $\begin{array}{l}\text { Meningkata } \\
\mathrm{n} \\
\text { profesionali } \\
\text { tas dan } \\
\text { kompetensi } \\
\text { SDM serta } \\
\text { meningkatk } \\
\text { an } \\
\text { manajemen } \\
\text { pengelolaan } \\
\text { Prodi }\end{array}$ & $\begin{array}{l}\text { Mewujudkan } \\
\text { institusi yang } \\
\text { sehat dan } \\
\text { penyelenggaraan } \\
\text { serta } \\
\text { pengelolaan } \\
\text { tridarma } \\
\text { perguruan tinggi } \\
\text { yang memenuhi } \\
\text { good } \\
\text { governance }\end{array}$ & $\begin{array}{l}\text { Mengutamakan } \\
\text { kepuasan } \\
\text { pelanggan } \\
\text { berdasarkan } \\
\text { regulasi yang } \\
\text { berlaku serta } \\
\text { selalu } \\
\text { melakukan } \\
\text { perbaikan yang } \\
\text { berkelanjutan }\end{array}$ & $100 \%$ \\
\hline
\end{tabular}

\section{Implementasi SPMI di Prodi Pendidikan Sejarah}

1. Dokumen Standar Mutu Prodi Pendidikan Sejarah

Prodi Pendidikan Sejarah FKIP Unmas Denpasar mengembangkan standar lebih atau melampui Standar Nasional Pendidikan Tinggi (SNDikti). Standar Nasional Pendidikan Tinggi (SNDikti) terdiri dari 24 (dua puluh empat) standar terdiri dari 8 (delapan) standar Pendidikan, 8 (delapan) standar Penelitian, dan 8 (delapan) standar Pengabdian kepada Masyarakat. Ditambah dengan standar Prodi lagi 12 (duabelas) standar, maka keseluruhan standar Prodi Pendidikan Sejarah berjumlah 36 standar, sehingga dapat dikatakan memiliki standar melampui SNDikti. Adapun 12 standar Prodi Pendidikan Sejarah FKIP Unmas Denpasar (Standar Dikti) yaitu: (1) Standar Profil Prodi,(2) Standar Visi dan Misi, (3) Standar Tata Pamong, (4) Standar Kemahasiswaan,(5) Standar Sistem Informasi, (6) Standar Kerjasama, (7) Standar Kesehatan Kampus, dan (8) Standar Keamanan Kampus, (9) Standar 
Praktek Laboratorium, (10) Standar Kuliah Kerja Nyata (KKN), (11) Standar Kuliah Kerja Lapangan (KKL), dan (12) Standar Praktek Pengalaman Lapangan (PPL/PLP). Implementasi standar mutu Prodi, selanjutnya dijelaskan dalam sejumlah dokumen SPMI Prodi Pendidikan Sejarah FKIP Unmas Denpasar berupa Buku yaitu: Kebijakan SPMI, Manual SPMI, Standar SPMI, dan Formulir SPMI.

\section{Siklus Pelaksanaan SPMI}

Prodi Pendidikan Sejarah melalui Unit Penjaminan Mutu dalam melaksanakan kendali mutu baik mutu akademik maupun non akademik menggunakan manajemen siklus dengan prinsip PPEPP yaitu Penetapan Standar, Pelaksanaan Standar, Evaluasi Standar, Pengendalian Standar, dan Peningkatan Standar. Hal ini sejalan dengan pernyataan Undang-Undang Nomor 12 Tahun 2012 Bab III Pasal 52 menyatakan bahwa penjaminan mutu Pendidikan Tinggi merupakan kegiatan sistemik untuk meningkatkan mutu Pendidikan Tinggi secara berencana dan berkelanjutan, serta dilakukan melalui penetapan, pelaksanaan, evaluasi, pengendalian, dan peningkatan standar Pendidikan Tinggi.

Dalam mengimplementasikannya dilaksanakan secara berjenjang, berkelanjutan, dan priodik dalam bentuk kegiatan yang sesuai dengan prinsip PPEPP, sehingga diharapkan dengan manajemen ini diperoleh peningkatan standar mutu secara berkelanjutan (kaizen atau continuous quality improvement) di Prodi Pendidikan Sejarah FKIP Unmas Denpasar. Prosedur proses penjaminan mutu dan sasaran mutu disesuaikan dengan Manual Implementasi SPMI.

Selanjutnya setiap langkah dari sikulus SPMI tersebut dapat dijelaskan sebagai berikut:

a. Penetapan Standar

Penetapan standar dimaksudkan merumuskan pernyataan dalam bentuk kalimat lengkap yang berisi sesuatu yang dicitakan atau diinginkan untuk dicapai, sesuatu tolok ukur atau kriterium atau spesifikasi tertentu, atau dapat juga berisi perintah untuk melakukan sesuatu (Direktorat Penjaminan Mutu, 2017:34). Prodi Pendidikan Sejarah dalam menetapkan standar mutu SNDikti, perkembangan regulasi, visi dan misi serta Core Value Prodi, hasil studi banding (benchmarking), hasil analisis SWOT dan hasil analisis terhadap studi kelayakan serta kepuasan stakeholders. Standar yang telah dirumuskan disosialisasikan sekaligus melakukan uji public kepada seluruh 
pemangku kepentingan pelaksanaan SPMI baik internal maupun ekternal untuk mendapat tanggapan, koreksi dan masukan semua pihak.

b. Pelaksanaan Standar.

Standar yang telah ditetapkan, selanjutnya dilaksanakan oleh para unit pengelola program dalam hal ini oleh Kaprodi, dosen, tenaga kependidikan, dan pelaksana unit penunjang akademik.

c. Evaluasi Standar.

Kegiatan evaluasi standar sebagai kegiatan memeriksa, mengukur, dan menilai serta melaporkan hasilnya kepada pengambil keputusan. Sehingga dalam siklus evaluasi standar tindakan yang dilakukan adalah melakukan (Monitoring dan Evaluasi Internal (Monevin). Monitoring dapat dilakukan pada saat kegiatan sedang berlangsung yang disebut dengan formative evaluation dan dapat juga dilaksanakan setelah kegiatan selesai (summative evaluation).

Baik formative evaluation maupun summative evaluation dilaksanakan untuk tujuan: (1) memastikan bahwa pelaksanaan standar Unmas Denpasar telah berjalan sesuai mutu, (2) mengantisipasi atau mengoreksi kesalahan pelaksanaan yang dapat menggagalkan tercapainya isi standar, (3) mempertahankan praktik baik yang telah dijalankan oleh para pelaksana standar. Termasuk tindakan summative evaluation adalah tindakan audit yang dilakukan oleh pihak internal yaitu oleh para pejabat struktural. Namun untuk menjaga objektivitas hasil audit, maka pelaksanaan audit dilakukan oleh tim audit mutu internal (AMI) yaitu para auditor internal yang ditetapkan oleh Rektor berdasarkan Surat Keputusan Rektor. Tim Auditor internal ini berada di bawah koordinasi Lembaga Penjaminan Mutu Internal (LPMI) Unmas Denpasar (Buku Panduan SPMI, 2017: 39). Selanjutnya dilakukan rumusan rencana tindak lanjut (RTL).

d. Pengendalian Standar

Pengendalian standar dilakukan oleh Kaprodi sebagai manajemen di prodi yang bertanggungjawab dalam pelaksanaan standar. Pengendalian standar dilakukan setelah ada kepastian hasil kajian dari tindakan evaluasi standar mutu. Tindakan pengendalian standar dapat dilakukan mulai dari melaksanakan rapat pimpinan untuk membahas hasil evaluasi sampai pada tindakan korektif berupa intruksi, teguran, peringatan, 
pengehntian kegiatan, investigasi atau pemeriksaan mendalam dan penjatuhan sanksi ringan, sedang, dan berat.

e. Peningkatan Standar

Peningkatan standar bermakna adanya peningkatan mutu yang disebut kaizen atau continuous quality improvement. Tindakan peningkatan standar dilakukan apabila tahap penetapan, pelaksanaan, evaluasi dan pengendalian standar telah terlampui. Mutu peningkatan standar ini dilakukan pada unsur Behaviour, Competence, Degree secara bersamaan ataupun secara parsial. Selanjutnya rumusan standar sebagai tindakan peningkatan standar tersebut harus disosialisaikan kepada seluruh pemangku kepentingan sekaligus sebagai upaya uji public sebagaimana tahapan tindakan pada tahap penetapan standar.

\section{Kegiatan Monev-in dan Audit}

Kegiatan monitoring dan evaluasi internal (Monev-in) yang dilakukan oleh UPM Prodi Pendidikan Sejarah sebagai langkah terorganisir. Sehingga kegiatan monev-in menjadi bagian yang tidak terpisahkan dengan SPMI di Prodi. Hal ini mengandung konsekuensi bahwa monevin dilakukan sejak perencanaan sampai dengan pelaksanaan program kerja prodi. Dalam kegiatan monev-in, disamping melakukan tindakan monitoring dan evaluasi, juga dilakukan tindakan audit terhadap bidang kegiatan akademik dan nonakademik secara menyeluruh di prodi. Kegiatan monev-in dikendalikan oleh UPM berkoordinasi dengan Kaprodi yang dilaksanakan secara berkala setiap akhir semester. Luas lingkup kerja tim monev-in meliputi input, proses, output, dan outcame. Terkait dengan input meliputi pengembangan sumber daya (resources Development) baik mahasiswa maupun tenaga pendidik dan tenaga kependidikan. Aspek proses meliputi pengembangan proses pendidikan (educational process development) meliputi proses pembelajaran, suasana akademik, sarana dan prasarana, sistem evaluasi hasil belajar. Terkait dengan tata kelola yang meliputi manajemen, Tata Pamong dan pengendalian mutu internal (internal manajement development). Persoalan output dan outcomes juga menjadi bidang yang tidak terlepas dari sasaran monev-in seperti jangka waktu penyelesian studi, besaran indek prestasi lulusan, lama waktu tunggu dapat diserap di dunia kerja, dan lainnya.

Kegiatan audit baik di bidang akademik maupun nonakademik, juga menyangkut upaya tindakan memeriksa kesesuaian komponen-komponen peningkatan mutu akademik dan 
nonakademik dengan standar yang telah ditetapkan. Memeriksa hasil proses pencapaian mutu, menyiapkan laporan kepada auditee sebagai dasar perbaikan mutu selanjutnya, menetapkan hasil audit sesuai standar atau tidak sesuai standar untuk selanjutnya apabila hasil audit tidak sesuai standar, maka harus dilakukan rencana Tindak Lanjut (RTL) oleh manajemen. Kegiatan tim monev-in dan audit tersebut, sekaligus berarti membantu institusi/fakultas/prodi dalam mempersiapkan diri untuk adanya monev ektrnal (Akreditasi oleh BAN-PT atau LAM). Kegiatan audit dilakukan secara priodik dengan jadwal yang disepakati oleh auditee.

Proses monev-in dilakukan sebagai upaya perbaikan mutu akademik secara kontinu (continuous quality improvement). Sebagai gambaran mengenai kegiatan monev-in diilustrasikan kedalam langkah-langkah sebagai berikut: (1) melakukan kajian dokumen, (2) melakukan survey (dengan pengamatan langsung atau checklist), melakukan fokus group discussion secara periodik dan diskusi masalah-masalah kasuistis di lapangan, dan (3) memberikan feedback. Selanjutnya membuat laporan hasil monev dan audit mutu internal kepada kepada Kaprodi untuk selanjutnya dibuatkan jurnal hasil monev dan audit setiap semester.

Sebagai tindakan baik yang dilakukan Prodi Pendidikan Sejarah dalam melaksanakan SPMI disamping melakukan prinsip PPEPP, juga secara berkelanjutan mengikuti kegiatan Universitas Mahasaraswati Denpasar Annual Quality Award (UMDAQA) sejak tahun 2010 sampai sekarang. Sebagai indicator tindakan baik pelaksanaan SPMI di prodi terbukti Prodi Pendidikan Sejarah memperoleh peringkat Juara II di tahun 2016 dan di tahun 2019 ini berada pada posisi Juara Utama dan terdapat relevansinya dengan hasil akreditasi prodi oleh BAN-PT pada tahun 2018 memperoleh status akreditasi sangat baik.

Monitoring dan evaluasi dilakukan dalam bentuk kunjungan kerja, wawancara, observasi dan penyebaran kuesioner. Tindakan monitoring dan evaluasi penjaminan mutu telah dilakukan berupa:

1. Menyebarkan kuesioner untuk mengukur tingkat kepuasan mahasiswa tentang pelayanan akademik seperti suasana proses pembelajaran, karakteristik dosen mengajar, pembimbingan akademik

2. Menyebarkan lembar dokumen agenda presensi dan materi kuliah bagi dosen dan presensi mahasiswa dalam mengikuti kuliah

3. Menyebarkan kuesioner untuk mengukur kepuasan alumni (lulusan) terhadap hasil belajarnya dikaitkan dengan pelaksanaan tugasnya

130 | Seminar Nasional Sejarah ke 4 Jurusan Pendidikan Sejarah Universitas Negeri Padang 
4. Menyebarkan kuesioner untuk mengukur persepsi mahasiswa baru tentang eksistensi Prodi Pendidikan Sejarah FKIP Unmas Denpasar dan kelanjutan studinya

5. Menyebarkan kuesioner untuk mengukur tingkat kepuasan kerja dosen danwan Unmas Denpasar

6. Menyebarkan kuesioner untuk mengukur tingkat kepuasan stakeholders terhadap kualitas lulusan prodi

7. Melakukan monitoring secara berkala kepada prodi, UPT, perpustakaan, dan laboratorium (UPT)

8. Melakukan monitoring dan evaluasi kepada dosen-dosen yang melaksanakan hibah penelitian dan PKM

9. Melakukan monitoring dan evaluasi terhadap kegiatan Unit Kegiatan Kemahasiswaan

10. Melakukan audit keuangan dan mutu akademik di prodi dan unit-unit pelayanan

\section{Simpulan}

Implemenatsi SPMI di Prodi Pendidikan Sejarah FKIP Unmas Denpasar senantiasa didasarkan atas tuntutan regulasi berkenaan dengan pengelolaan Pendidikan tinggi. Pada saat ini Prodi Pendidikan Sejarah telah menetapkan 36 (tiga puluh enam) standar terdiri dari 24 (dua puluh empat) SN Dikti dan 12 (dua belas) SDikti.

Sesuai ketentuan Pedoman SPMI Pendidikan Tinggi Direktorat Penjaminan Mutu Prodi Pendidikan Sejarah FKIP Unmas Denpasar telah memiliki dokumen seperti Buku Kebijakan SPMI, Manual SPMI sesuai jumlah standar berjumlah 180 eksemplar (sesuai siklus PPEPP), Standar SPMI, Formulir SPMI, 49 (empat puluh sembilan) Standar Operasional Prosedur (SOP). 9 (Sembilan) Instruksi Kerja (IK), dokumen hasil monevin dan audit setiap akhir tahun terdokumentir di prodi dan Unit Penjaminan Mutu (UPM) Prodi Pendidikan Sejarah FKIP Unmas Denpasar.

Berbagai langkah kegiatan SPMI senantiasa dilakukan oleh Kaprodi bersama UPM secara berencana dan berkelanjutan sesuai kebijakan manajemen. Pelaksanaan monev dan audit senantiasa dikomunikasikan untuk mendapat persetujuan auditi baik waktu pelaksanaan maupun hasil kegiatan monev dan audit. Untuk selanjutnya, seluruh hasil monev dan audit ditandatangani bersama, kemuadian disusun Rencana Tindak Lanjut (RTL). Seluruh tindakan terencana dari merumuskan kebijakan SPMI, pengadaan dokumen operasional, pelaksanaan monev dan audit, 
sampai dengan menyusun rencana tindak lanjut merupakan siklus tindakan baik dalam pelaksanaan SPMI di Prodi Pendidikan Sejarah FKIP Unmas Denpasar.

\section{DAFTAR PUSTAKA}

Undang-Undang RI Nomor 20 Tahun 2003 tentang Sistem Pendidikan Nasional

Undang-Undang RI Nomor 12 Tahun 2012 tentang Pendidikan Tinggi

Peraturan Presiden Republik Indonesia Nomor 8 Tahun 2012 tentang Kerangka Kualifikasi Nasional Indonesia (KKNI)

Permendikbud RI Nomor 4 tahun 2014 tentang Penyelenggaraan Pendidikan Tinggi dan Pengelolaan Perguruan Tinggi

Permenristekdikti RI Nomor 44 tahun 2015 tentang Standar Nasional Pendidikan Tinggi

Permenristek Dikti RI Nomor 32 Tahun 2016 tentang Akreditasi Program Studi dan Perguruan Tinggi

Permenristek Dikti RI nomor 61 Tahun 20176 tentang Pangkalan data Pendidikan Tinggi

Permenristek Dikti RI Nomor 62 tahun 2016 tentang Sistem Penjaminan Mutu Pendidikan Tinggi

Kebijakan Nasional Sistem Penjaminan Mutu Internal (SPMI) Perguruan Tinggi, Kemendikbud RI Dikti Dirbelmawa tahun 2013.

Pedoman Sistem Penjaminan Mutu Internal (SPMI) Perguruan Tinggi, Kemenristek Dikti Dirjen Dirbelmawa Direktorat Penjaminan Mutu 2017

Statuta Universitas Mahasaraswati Denpasar

Buku Kebijakan Sistem Penjaminan Mutu Internal (SPMI) Unmas Denpasar Tahun 2017 